\title{
KEBIJAKAN PENGEMBANGAN KOLEKSI DI PERPUSTAKAAN SEKOLAH TINGGI PEMBANGUNAN MASYARAKAT DESA (STPMD) YOGYAKARTA
}

\author{
Septevan Nanda Yudisman, Lailatur Rahmi \\ Prodi D3 IImu Perpustakaan Fakultas Adab dan Humaniora UIN Imam Bonjol Padang \\ email: septevannanda@gmail.com, lailaturrahmi@uinib.ac.id
}

\begin{abstract}
Abstrak
Kebijakan Pengembangan koleksi merupakan prosedur yang mengatur dalam mengalokasikan sumber daya informasi di perpustakaan, bertujuan untuk menentukan apa yang harus dikembangkan dan menentukan peningkatan layanan. Penelitian ini bertujuan untuk memberikan masukan kepada perpustakaan terhadap kebijakan pengembagan koleksi di Perpustakaan Sekolah Tinggi Pembangunan Masyarakat Desa Yogyakarta. Tulisan ini akan mencoba menghasilkan suatu pedoman Kebijakan Pengembangan Koleksi di Perpustakaan Perguruan Tinggi. Kebijakan Pengembangan koleksi yang disusun menjadi usulan penulis sebagai masukan bagi perpustakaan untuk ditindak lanjuti penerapannya. Sebagai masukan dalam membuat kebijakan ataupun ketika merevisi kebijakan yang telah ada.
\end{abstract}

\author{
Kata Kunci: \\ Pengembangan \\ Koleksi, Seleksi, Evaluasi \\ Koleksi, Perpustakaan \\ Perguruan Tinggi
}

\section{A. PENDAHULUAN}

Perpustakaan perguruan tinggi merupakan lembaga informasi yang memainkan peran penting bagi civitas akademikanya, hal ini ditunjukkan dengan tingginya minat pengguna dalam penelusuran informasi melalui berbagai koleksi yang ada di Perpustakaan. Untuk memenuhi kebutuhan pengguna perpustakaan diharuskan untuk terus meningkatkan layanan yang diberikan terutama dari segi ketersediaan koleksi. Pemenuhan kebutuhan ini salah satunya dilakukan melalui pengembangan koleksi agar selalu up to date dan mengikuti perkembangan ilmu pengetahuan. Keberadaan koleksi bagi perpustakaan sangatlah penting, mengingat sumber informasi yang ada didalamnya menjadi kebutuhan yang dicari oleh pengguna.

Pustakawan sebagai pengelola tentu perlu memperhatikan agar pengembangan koleksi terus berjalan sesuai prosedur, untuk itu perlu dibuatkan kebijakan agar pengembangan dapat terlaksana melalui mekanisme yang pas. Kebijakan sebagai seperangkat prinsip dan strategi yang akan menjadi panduan mengenai tindakan yang akan dilakukan untuk mencapai tujuan yang telah ditentukan sebelumnya. Kebijakan ini bisa dikembangkan dalam level organisasi atau institusi (micropolicies), atau juga dalam tingkat regional, nasional, dan internasional (Montviloff, 1990).

Kebijakan biasanya berasal dari sebuah keputusan awal dan menjadi pernyataan atau pengertian umum yang menjadi saluran berpikir dalam pengambilan keputusan di masa depan. Kebijakan ini biasanya berfungsi untuk memastikan bahwa keputusan yang diambil masih sesuai dengan filosofi dan tujuan organisasi. Syihabuddin menyatakan bahwa Kebijakan pengembangan koleksi dapat dilaksanakan secara terarah dan kebijakan pengembangan koleksi harus disusun secara tertulis (Qalyubi, 2007). Karena tanpa adanya kebijakan tertulis, kesalah pahaman bisa saja terjadi sehingga pengembangan koleksi ke arah koleksi yang mutakhir dan relevan dengan kebutuhan pengguna tidak akan terpenuhi.

Perpustakaan Sekolah Pembangunan Masyarakat Desa (STPMD) Yogyakarta merupakan salah satu perpustakaan di bawah naungan lembaga perguruan tinggi swasta yang ada di Yogyakarta. Pengguna Perpustakaan STPMD terdiri dari dosen, pegawai dan mahasiswa dengan lima program studi yaitu SI DAN S2 Ilmu Pemerintahan, SI IImu sosiatri, SI IImu Komunikasi, dan D3 IImu Pembangunan Masyarakat desa. 
Kebijakan Pengembangan Koleksi di Perpustakaan Sekolah Tinggi Pembangunan Masyarakat Desa (STPMD) Yogyakarta

S. N. Yudisman, L. Rahmi

Perpustakaan Sekolah Pembangunan Masyarakat Desa Yogyakarta (STPMD) memiliki tenaga perpustakaan 4 orang. 1 (satu) orang sebagai kepala perpustakaan dengan kualifikasi pendidikan S1 Ilmu Perpustakaan, 3 (tiga) orang staf yang memiliki kualifikasi pendidikan 1 (satu) orang D3 IImu perpustakaan, 2 (Dua)orang IImu komunikasi. Di perpustakaan belum memiliki struktur organisasi perpustakaan. Adapun dari masyarakat yang dilayani perpustakaan memiliki 1. 849 orang. Yang terdiri dari dosen, staff/karyawan, serta mahasiswa. Dari segi koleksi memiliki koleksi dengan rincian buku sebanyak 7.717 Judul, skripsi 8.815 Eksemplar, tesis 207 eksemplar, majalah 8 judul, Koran 3 redaksi. Perpustakaan Sekolah Pembangunan Masyarakat Desa Yogyakarta (STPMD) membuka layanan dari pukul 08.00 s/d 19.00 WIB. Layanan perpustakaan dibuka dari hari senin s/d Jum'at. Fasilitas yang dimiliki yaitu terdiri dari ruang koleksi, ruang baca, OPAC, WiFi. Sebagai sumber informasi di lingkungan perguruan tinggi dan berperan sebagai salah satu penunjang pilar Tri Dharma Perguruan Tinggi yaitu pendidikan, penelitian dan pengabdian masyarakat perpustakaan STPMD berusaha memenuhi kebutuhan informasi yang sesuai dengan kebutuhan pengguna, dengan harapan dapat berdaya guna sebagaimana fungsinya.

Perpustakaan sebagai sumber informasi seharus dapat digunakan dengan baik oleh penggunanya, namun dari data kunjungan dan peminjaman perpustakaan STPMD 3 tahun terakhir cukup rendah jika dilihat dari jumlah pengguna. Data ini terlihat dari data kunjungan dan peminjaman yang penulis lampirkan. Salah satu rendahnya pendayagunaan perpustakaan disebabkan koleksi perpustakaan banyak yang sudah tidak relevan dengan kebutuhan pengguna. koleksi yang ada di perpustakaan sudah banyak yang tidak up to date.

Merujuk pada tulisan Peggy Johnson, mengenai kebijakan pengembangan koleksi dalam bukunya "Fundamentals of Collection Devel- opment and Management", bagian appendix dia mencoba memberikan beberapa contoh mengenai penerapan kebijakan pengembangan koleksi di beberapa Perpustakaan (Jhonson, 2009). Dalam tulisan ini saya akan mencoba menyusun suatu pedoman Kebijakan Pengembangan Koleksi di Perpustakaan Perguruan Tinggi. Kebijakan Pengembangan koleksi yang disusun menjadi usulan penulis sebagai masukan bagi perpustakaan untuk ditindak lanjuti penerapannya. Sebagai masukan dalam membuat kebijakan ataupun ketika merevisi kebijakan yang telah ada.

\section{B. KAJIAN TEORITIS}

\section{Pengertian Pengembangan Koleksi Perpus- takaan}

Bahan pustaka dapat dikembangkan dengan menambah jenis maupun kuantitasnya. Evans dan saponaro memberikan batasan istilah "collection development" sebagai suatu proses untuk mengetahui peta kekuatan dan kekurangan atau kelemahan koleksi perpustakaan, sehingga dengan demikian akan tercipta sebuah rencana (Planning) untuk memperbaiki peta kelemahan dan mempertahankan kekuatan koleksi (Evan \& Saponaro, 2005).

Pengembangan koleksi adalah sejumlah kegiatan yang berkaitan dengan penentuan dan koordinasi kebijakan seleksi, menilai kebutuhan pemakai, studi pemakaian koleksi, evaluasi koleksi, identifikasi kebutuhan koleksi, seleksi bahan pustaka, perencanaan kerjasama sumberdaya koleksi, pemeliharaan koleksi, dan penyiangan koleksi perpustakaan (Kohar, 2003). Menurut adam dan novel, pengembangan koleksi merupakan salah satu faktor yang amat penting untuk meningkatkan kualitas perpustakaan dan merupakan aspek yang paling mahal dalam pengoperasian perpustakaan (Adams \& Noel, 2008). Dengan adanya pendapat tersebut maka pengembangan koleksi dalam perpustakaan merupakan serangkaian kegiatan yang digunakan untuk menganalisa koleksi 
sehingga dapat menghasilkan sebuah perpustakaan yang memiliki sumber daya yang dapat digunakan secara maksimal oleh penggunanya. adapun tahapan-tahapan dalam pengembangan koleksi adalah analisis pengguna, kebijakan, seleksi, akuisisi/pengadaan, weeding dan evaluasi (Evan \& Saponaro, 2005).

\section{Kebijakan Pengembangan Koleksi Perpus- takaan}

Menurut Johnson bahwa perpustakaan yang berjalan tanpa memiliki kebijakan pengembangan koleksi sama seperti menjalankan sebuah organisasi tanpa adanya rencana kedepan (Jhonson, 2009). Artinya Jika sebuah organisasi berjalan tanpa rencana maka setiap kegiatan yang akan dilakukan tidak dapat berjalan dengan terarah. Qalyubi (2007) menjelaskan agar kebijakan pengembangan koleksi dapat dilaksanakan secara terarah, kebijakan pengembangan koleksi harus disusun secara tertulis. Tanpa adanya kebijakan tertulis, kesalah pahaman akan terjadi antara satu staf dengan staf yang lainnya sehingga pengembangan koleksi kearah koleksi yang mutakhir dan relevan tidak akan terpenuhi.

Setiap perpustakaan tentu memiliki kebijakan pengembangan koleksi yang berbeda seperti yang dikatakan oleh Darmono bahwa kebijakan pengembangan koleksi antara satu perpustakaan dengan perpustakaan yang lain isinya akan berbeda-beda (Darmono, 2001). Perbedaan ini akan dipengaruhi oleh beberapa faktor seperti kebijakan pemerintah, kondisi ekonomi yang akan berpengaruh terhadap kebijakan pendanaan, suasana dan lingkungan pendidikan, keadaan penerbitan, kebiasaan pemakai, sikap masyarakat serta faktor-faktor lain yang bersifat lokal. Sehubungan dengan berbagai faktor tadi, sehingga kesamaan standar untuk pengembangan koleksi perpustakaan akan sulit untuk dirumuskan.

Masing-masing perpustakaan akan memiliki kebijakan pengembangan koleksi yang berbe- da-beda. Sesuai faktor-faktor yang mempengaruhinya.

\section{a. Analisis Komunitas (community analysis)}

Menurut greer dan Hale analisis komunitas merupakan proses yang sistematis untuk mengumpulkan, mengatur, dan menganalisis data tentang sebuah komunitas dan perpustakaan yang ada pada komunitas tersebut (Greer \& Hale, 1985). Analisis komunitas dirancang untuk membantu staf perpustakaan dalam menentukan pola kebutuhan informasi dan minat seluruh komunitas atau masyarakat yang menjadi pengguna perpustakaan.

\section{b. Seleksi}

Setelah mengetahui kebijakan seleksi tahap selanjutnya adalah proses seleksi. Menurut Magrill Corbin dalam Qalyubi (2007) bahwa secara umum seleksi diartikan sebagai tindakan, cara, atau proses memilih. Dalam hubungan dengan pengembangan koleksi perpustakaan, seleksi merupakan kegiatan untuk mengidentifikasi rekaman informasi yang akan ditambahkan pada koleksi yang sudah akan ditambahkan pada koleksi yang sudah ada di perpustakaan proses yang dilakukan pada tahap ini adalah keputusan untuk mencantumkan atau tidak rekaman informasi yang direncanakan untuk diadakan perpustakaan.

Personalia atau kelompok yang dipandang memiliki kapabilitas untuk menyeleksi bahan pustaka antara lain, adalah pustakawan, spesialis subjek, toko buku, dan komisi perpustakaan.

Menurut Qalyubi (2007) pada perpustakaan perguruan tinggi otoritas yang melaksanakan seleksi adalah pimpinan universitas, dekan, ketua jurusan/program studi, dan dosen. Pembentukan komisi penasehat/pengawas perpustakaan secara khusus juga dapat memilih atau menyarankan agar melanggan terbitan berkala tertentu sebagai tugasnya. Komisi ini biasanya terdiri atas pustakawan, dosen, dekan dan elemen-elemen yang dipandang mampu. Mahasiswa dimungkinkan 
memberikan usulan, tetapi dengan mempertimbangkan keselarasan kebutuhan perkuliahan.

Alat bantu seleksi berguna untuk membantu pustakawan dala memutuskan apakah bahan pustaka perlu diseleksi atau tidak. Beberapa bentuk alat bantu seleksi antara lain:

1. Majalah tinjauan buku (Reviewing Journals)

2. Daftar judul untuk perpustakaan tertentu (core list)

Selain itu juga beberapa bentuk alat identifikasi dan verifikasi seperti katalog penerbit, berbagai bibliografi (bibliografi nasional, book in print, publisher's trade list annual), dan indeks (book review digest, book review index, Technical Book Review Index )

\section{c. Pengadaan}

Secara sederhana, pengadaan bahan pustaka dapat dilakukan lewat pembelian, tukar menukar, hadiah, atau dengan menerbitkan sendiri.

\section{d. Penyiangan}

Penyiangan (Weeding) bahan pustaka/koleksi merupakan salah satu cara dalam melakukan pengembangan koleksi. Koleksi perpustakaan yang hidup dan berkembang akan selalu bertambah, pada akhirnya banyak buku yang tidak bermanfaat lagi, misalnya karena isinya sudah usang atau sudah ada cetakan (edisi) yang lebih baru. Selain itu penyebabnya adalah tidak selalu diikuti oleh perkembangan ruang atau gedung. Kemampuan ruangan atau gedung untuk menampung koleksi selalu terbatas, sehingga pustakawan harus mencari jalan keluar agar pertambahan koleksi selalu dapat ditampung. Salah satu cara yang dapat dilakukan adalah dengan cara mengadakan penyiangan bahan pustaka/koleksi.

Penyiangan secara sederhana dipahami sebagai usaha untuk mengeluarkan atau menarik bahan pustaka dari koleksi (Qalyubi, 2007). Sebelum bahan pustaka dimasukkan ke dalam jajaran koleksi perpustakaan, bahan tersebut harus evaluasi. Demikian juga koleksi yang telah ada, re evaluasi tetap diperlukan secara periodic untuk melihat apakah nantinya bahan pustaka masih bernilai bagi pemakai koleksi yang bersangkutan.

Tujuan weeding/ penyiangan menurut Evans dan Saponaro, ada empat tujuan yang akan dicapai mengapa penyiangan dilakukan, antara lain (Evan \& Saponaro, 2005):

3). Memperoleh tambahan tempat (shelf space) untuk koleksi yang baru

4). Membuat koleksi lebih dapat dimanfaatkan sebagai sumber informasi yang akurat, relevan, up to date, serta menarik

5). Memberikan kemudahan pada pemakai dalam menggunakan koleksi

6). Memungkinkan staf perpustakaan mengelola koleksi secara lebih efektif dan efisien.

Penyiangan/deseleksi secara sederhana dipahami sebagai usaha untuk mengeluarkan atau menarik bahan pustaka dari koleksi. Sebelum bahan pustaka dimasukkan dalam jajaran koleksi perpustakaan, bahan tersebut harus dievaluasi. Demikian juga koleksi yang telah ada, re evaluasi tetap diperlukan secara periodic untuk melihat apakah nanti bahan pustaka masih bernilai bagi pemakai koleksi yang bersangkutan.

\section{e. Evaluasi}

Agar kebutuhan informasi pengguna dapat terpenuhi, koleksi yang ada di perpustakaan harus sesuai dengan kebutuhan mereka. Untuk menjaga agar koleksi yang ada selalu up to date dan sesuai dengan kebutuhan pengguna maka harus dilakukan evaluasi koleksi perpustakaan secara berkala. Evaluasi koleksi diperlukan untuk mengetahui seberapa baik kualitas koleksi perpustakaan berkaitan dengan relevansinya dengan kebutuhan pengguna. Tujuan secara umum dari evaluasi koleksi adalah untuk menentukan kualitas koleksi dan juga mengetahui apakah tujuan perpustakaan telah ditentukan telah tercapai (Yulia, 2009). 
Evaluasi koleksi berarti menilai atau mengukur kualitas kegunaan atau manfaat koleksi perpustakaan terhadap pengguna, misalnya di perpustakaan sekolah, kegunaan koleksi untuk membantu kegiatan belajar mengajar di sekolah. Olausson mengungkapkan dengan melakukan evaluasi berarti kita menilai suatu kegiatan yang telah ditetapkan sebelumnya dengan cara mengumpulkan data, mendeskripsikan, analisis, dan menginterpretasikan.

Gorman dan Howes (1991) mengungkapkan tujuan dilaksanakannya evaluasi koleksi di perpustakaan, yaitu:

1). Mengetahui secara akurat pemahaman atas cakupan, kedalaman an kegunaan dari koleksi

2). Untuk mempersiapkan sebuah pedoman dasar bagi pengembangan koleksi

3). Untuk membantu dalam menyusun kebijakan pengembangan koleksi

4). Untuk mengukur efektifitas atau keberhasilan kebijakan pengembangan koleksi

5). Untuk menentukan kecukupan dan kualitas koleksi

6). Untuk meralat kekurangan dalam daftar koleksi yang akan diadakan perpustakaan, dan memberikan jalan untuk mengatasinya

7). Untuk memfokuskan sumber daya keuangan dan sumber daya manusia pada bidang yang paling membutuhkan perhatian

8). Untuk memberikan argumentasi dalam tujuannya untuk meningkatkan anggaran koleksi

9). Untuk memberitahukan kepada administer mengenai sesuatu yang telah dilakukan sehubungan dengan permintaan peningkatan anggaran

10). Membangun kekuatan khusus (special core) dalam koleksi yang ada
11). Pedoman untuk melaksanakan penyiangan dan pengawasan koleksi, dan menyusun prioritas selanjutnya.

Menurut Wotman ada beberapa metode yang dapat digunakan untuk melaksanakan evaluasi, di antaranya adalah dengan membandingkan koleksi perpustakaan dengan daftar judul standar yang harus dimiliki, kajian sirkulasi, survey pendapat pengguna, dan sebagainya. Melalui kegiatan evaluasi ini, dapat diketahui koleksi apa yang banyak dimanfaatkan dan koleksi apa yang sudah tidak digunakan lagi oleh pengguna. Kemudian, hasil evaluasi tersebut dapat dimanfaatkan oleh perpustakaan dalam melakukan pengembangan koleksi di kemudian hari. Apabila kegiatan evaluasi koleksi di perpustakaan sekolah sudah dapat berjalan secara berkala dan berkesinambungan, maka dapat dipastikan koleksi yang ada di perpustakaan dapat memenuhi kebutuhan informasi penggunanya. semakin tinggi kebutuhan pengguna akan semakin meningkat. Sehingga tujuan dari keberadaan perpustakaan sekolah menjadi terwujud.

\section{METODE PENELITIAN}

Penelitian ini termasuk penelitian lapangan ( field research ) yaitu : "Suatu penelitian yang dilakukan secara sistematis dengan mengangkat data yang ada di lapangan (Suharsimi, 1995). Metode yang digunakan pada penelitian ini adalah menggunakan metode penelitian kualitatif. Dimana menurut Bodgan dan Taylor, metodologi kualitatif adalah prosedur penelitian yang menghasilkan data deskriptif berupa kata-kata tertulis atau lisan dari orang-orang dan perilaku dapat diamati. Pendekatan ini diarahkan pada latar dan individu tersebut secara utuh (Lexi, 2008).

\section{HASIL DAN PEMBAHASAN}

Secara umum pernyataan kebijakan pengembangan koleksi perpustakaan mencakup tentang: 


\section{MISSION STATEMENT}

Perpustakaan Sekolah Pembangunan Masyarakat Desa (STPMD) Yogyakarta merupakan salah satu perpustakaan di bawah naungan lembaga perguruan tinggi swasta yang ada di Yogyakarta. Pengguna Perpustakaan STPMD terdiri dari dosen, pegawai dan mahasiswa dengan lima program studi yaitu SI DAN S2 IImu Pemerintahan, SI IImu sosiatri, SI IImu Komunikasi, dan D3 IImu Pembangunan Masyarakat desa. Dengan total pengguna 1849 pengguna. Perpustakaan Sekolah Tinggi Pembangunan Masyarakat memiliki visi (Menjadi perpustakaan yang unggul dalam menyediakan sumber-sumber informasi dengan layanan teknologi terkini) guna mewujudkan visi tersebut.

Perpustakaan Sekolah Pembangunan Masyarakat Desa Yogyakarta (STPMD) memiliki tenaga perpustakaan 4 orang. 1 (satu) orang sebagai kepala perpustakaan dengan kualifikasi pendidikan S1 Ilmu Perpustakaan, 3 (tiga) orang staf yang memiliki kualifikasi pendidikan 1 (satu) orang D3 Ilmu perpustakaan, 2 (Dua)orang Ilmu komunikasi. Di perpustakaan belum memiliki struktur organisasi perpustakaan. Adapun dari masyarakat yang dilayani perpustakaan memiliki 1. 849 orang. Yang terdiri dari dosen, staff/karyawan, serta mahasiswa. Dari segi koleksi memiliki koleksi dengan rincian buku sebanyak 7.717 Judul, skripsi 8.815 Eksemplar, tesis 207 eksemplar, majalah 8 judul, Koran 3 redaksi. Perpustakaan Sekolah Pembangunan Masyarakat Desa Yogyakarta (STPMD) membuka layanan dari pukul 08.00 s/d 19.00 WIB. Layanan perpustakaan dibuka dari hari senin s/d Jum'at. Fasilitas yang dimiliki yaitu terdiri dari ruang koleksi, ruang baca, OPAC, WiFi.

Perpustakaan Sekolah Tinggi Pembangunan Masyarakat Desa (STPMD) Yogyakarta terus memperhatikan pengembangan koleksi, melalui suatu kebijakan maka akuisisi dan pengembangan yang dilakukan dapat terlaksana melalui suatu pedoman tertulis agar terlaksana sesuai tujuan yang ditetapkan bersama. Pentingnya kebijakan makin perlu dirasakan ketika melihat begitu cepatnya penambahan koleksi dalam berbagai bentuk, pemenuhan kebutuhan informasi pengguna dan bagaimana pustakawan agar terus dapat mengembangkan koleksi agar sesuai dengan perkembangan ilmu pengetahuan.

\section{VISI DAN MISI PERPUSTAKAAN}

Perpustakaan Sekolah Pembangunan Masyarakat Desa (STPMD) Yogyakarta merupakan salah satu perpustakaan di bawah naungan lembaga perguruan tinggi swasta yang ada di Yogyakarta. Pengguna Perpustakaan STPMD terdiri dari dosen, pegawai dan mahasiswa dengan lima program studi yaitu SI DAN S2 IImu Pemerintahan, SI Ilmu sosiatri, SI IImu Komunikasi, dan D3 IImu Pembangunan Masyarakat desa. Dengan total pengguna 1849 pengguna. Perpustakaan Sekolah Tinggi Pembangunan Masyarakat Desa memiliki visi Menjadi perpustakaan yang unggul dalam menyediakan sumber-sumber informasi dengan layanan teknologi terkini guna mewujudkan visi tersebut.

Maka telah ditetapkan juga misi sebagai berikut:

a. Mengembangkan perpustakaan yang berorientasi tentang pedesaan

b. Mengembangkan koleksi perpustakaan dalam mendukung proses belajar mengajar, penelitian, dan sosial kemasyarakatan

c. Mengembangkan sarana dan prasarana perpustakaan untuk memberikan layanan prima berbasis teknologi informasi dan komunikasi

\section{TUJUAN KEBIJAKAN PENGEMBANGAN KOLEKSI}

Kebijakan pengembangan koleksi diharapkan dapat terlaksana secara terarah, dengan tujuan untuk:

a. Menggambarkan ruang lingkup koleksi, sifat dan prioritas koleksi.

b. Menyediakan kerangka kerja bagi pengelola 
dan pengembangan koleksi perpustakaan, menunjukkan prioritas, dan menetapkan kriteria seleksi

c. menciptakan dasar yang konsisten dan koheren dalam pengembangan koleksi di masa depan.

d. Memberikan panduan untuk para staf dalam seleksi, ketentuan menjadi pertimbangan dalam pengembangan koleksi dan seleksi bukan lagi dipertimbangkan oleh individu dari pengalamannya akan tetapi dapat ditetapkan oleh kebijakan secara jelas.

e. Memfasilitasi kolaborasi antara pustakawan di lembaga dan dapat membantu pengembangan secara koheren.

Adapun tujuan kebijakan pengembangan koleksi yang utama pada Perpustakaan Perguruan Tinggi adalah untuk mendukung instruksi fakultas, mahasiswa, dosen, dan peneliti. Salah satu upaya yang dilakukan dalam mempertahankan eksistensi perpustakaan melalui pengembangan koleksi dalam berbagai format.

\section{RUANG LINGKUP DAN AKSES KOLEKSI}

Perpustakaan Sekolah Tinggi Pembangunan Masyarakat Desa (STPMD) Yogyakarta turut berperan dalam mendukung proses belajar mengajar, dengan menyediakan berbagai macam jenis koleksi dalam berbagai format dan akses koleksi yang memberikan kenyaman bagi pengguna. Koleksi perpustakaan tersedia untuk digunakan pada tempat yang telah disediakan dan koleksi dapat digunakan bagi siapa saja yang terdaftar sebagai anggota secara bebas di perpustakaan. Melalui kebijakan perpustakaan mendukung dalam memfasilitasi keterampilan mereka, melengkapi kebutuhan pendidikan dan merangsang minat mereka.

\section{STANDAR KOLEKSI PERPUSTAKAAN}

Merujuk pada standar yang dikeluarkan oleh Perpustakaan Nasional terhadap standar koleksi di Perpustakaan Perguruan Tinggi (SNP: 010/2011). Berikut standar yang ditetapkan: a. Jenis dan jumlah koleksi - Koleksi perpustakaan berbentuk karya tulis, karya cetak, dan/ atau karya rekam terdiri atas fiksi dan nonfiksi. - Koleksi nonfiksi terdiri atas buku wajib mata kuliah, bacaan umum, referensi, terbitan berkala, muatan lokal, laporan penelitian, dan literatur kelabu.

a). Jumlah buku wajib dihitung menggunakan rumus 1 program studi X (144 sks dibagi 2 sks per mata kuliah) $X 2$ judul permata kuliah $=144$ judul buku wajib per program studi.

b). Judul buku pengembangan $=2 \mathrm{X}$ jumlah buku wajib.

c). Koleksi AV (judul) $=2 \%$ dari total jumlah judul koleksi non AV.

d). Jurnal ilmiah minimal 1 judul (berlangganan atau menerima secara rutin) per program studi. - Majalah ilmiah populer minimal 1 judul (berlangganan atau menerima secara rutin) per program studi. - Muatan lokal (local content) yang terdiri dari hasil karya ilmiah civitas akademika (skripsi, tesis, disertasi, makalah seminar, simposium, konferensi, laporan penelitian, laporan pengabdian masyarakat, laporan lain-lain, pidato pengukuhan, artikel yang dipublikasi di media massa, publikasi internal kampus, majalah atau buletin kampus).

a. Penambahan koleksi $1 \%$ dari total koleksi (judul) yang sudah ada, atau minimal 1 judul untuk 1 mata kuliah, dipilih yang lebih besar.

b. Koleksikhusus Perpustakaan menyediakan koleksi khusus perpustakaan perguruan tinggi, yaitu bahan perpustakaan berupa hasil penelitian, skripsi, tesis dan disertasi minimal 1.000 judul.

c. Bahan perpustakaan referensi, Perpustakaan menyediakan bahan perpustakaan referensi. Koleksi bahan perpustakaan referensi minimal meliputi kamus umum 
bahasa Indonesia dan kamus bahasa Inggris - Indonesia, kamus bahasa Indonesia-Inggris, kamus bahasa daerah, kamus bahasa Jerman-Indonesia, kamus bahasa Indonesia-Jerman, kamus bahasa Perancis-Indonesia, kamus bahasa Indonesia-Perancis, kamus bahasa Jepang-Indonesia, kamus bahasa Indonesia-Jepang, kamus bahasa Mandarin-Indonesia, kamus bahasa Indonesia-Mandarin, kamus bahasa Indonesia-Arab, kamus bahasa Arab-Indonesia, kamus subjek, ensiklopedi, sumber biografi, atlas, peta, bola dunia, direktori (terutama buku telepon).

Kebijakan seleksi merupakan bagian dari kebijakan pengembangan koleksi. Pada umumnya kebijakan seleksi berisi tentang kriteria seleksi, fungsi seleksi, dan apa yang menjadi tolok ukur dalam kegiatan seleksi. Kebijakan ini diperlukan untuk membantu selector dalam memilih materi yang akan dijadikan koleksi perpustakaan dan mana yang tidak.

Kegiatan yang dilakukan adalah merumuskan persentase koleksi yang harus di seleksi untuk setiap kelas subjek yang ada. Di Perpustakaan STPMD ada lima program studi.

- Persentase Komposisi pengadaan buku berdasarkan program studi

a. Pemberdayaan Masyarakat Desa (20\%)

b. Ilmu Sosiatri (20\%)

c. Ilmu Pemerintahan (30\%)

d. IImu Komunikasi (20\%)

e. Lain-lain (10\%)

- $\quad$ Bahasa: Indonesia $90 \%$, asing 10\%

- Jurnal nasional 80\%

- Internasional : 20\%

Penetapan persentase ini di dapatkan melalui analisis silabus, serta pertimbangan kapasitas pengguna setiap prodi dan wawancara dengan kepala perpustakaan. Persentase ini baru bersifat sementara karena akan hasil draf ini akan dirapatkan kembali kepada penjaminan mutu lembaga induk dan Ka. Prodi yang ada di Sekolah Tinggi Perpustakaan Masyarakat Desa Yogyakarta.

\section{ANALISIS KEBUtUHAN PENGEMBANGAN KOLEKSI}

a. Analisis Masyarakat

Analisis masyarakat merupakan usaha untuk mengetahui bahan pustaka apa yang benar-benar dibutuhkan oleh masyarakat pengguna perpustakaan, dan mengetahui populasi yang dilayani. Kegiatan ini dilakukan dengan cara:

1). Analisis kurikulum untuk mendapatkan data populasi pengguna perpustakaan, dan kebutuhan-kebutuhan informasi yang relevan dengan kurikulum yang ada.

2). Wawancara kepada pengguna dan kepala perpustakaan Sekolah Tinggi Pembangunan Masyarakat Desa Yogyakarta

b. Analisis kebijakan seleksi

Kebijakan seleksi merupakan menetapkan rincian-rincian sebagai pedoman staf perpustakaan dalam pengembangan koleksi. Kebijakan adalah sarana yang membimbing staf dalam pengambilan keputusan. kegiatan-kegiatan yang dilakukan yaitu: 1). Wawancara dengan kepala perpustakaan untuk mengetahui kebijakan dalam menentukan rincian-rincian dalam pengembangan koleksi.

2). Wawancara dengan kepala perpustakaan mengetahui siapa saja yang terlibat dalam kebijakan seleksi.

c. Analisis seleksi

Seleksi merupakan sebuah tindakan, cara, atau proses memilih. Atau dengan kata lain mengidentifikasi rekaman informasi yang akan ditambahkan dalam hal ini ada beberapa kegiatan yang dilakukan yaitu:

1). Mengetahui pandangan yang digunakan dalam membanqun suatu koleksi 
2). Mengetahui kriteria-kriteria yang ditentukan dalam seleksi.

\section{d. Analisis pengadaan}

Pengadaan merupakan implementasi dari keputusan dalam melakukan seleksi yang mencakup semua kegiatan untuk mendapatkan bahan pustaka. Kegiatan yang dilakukan dalam hal ini yaitu:

1). Mengetahui sumber-sumber pengadaan bahan pustaka

2). Mengetahui

pertimbangan-pertim-

bangan dalam penerimaan dengan cara hadiah.

e. Analisis penyiangan

Penyiangan secara sederhana dipahami sebagai usaha untuk mengeluarkan untuk menarik bahan koleksi. Kegiatan yang dilakukan dalam analisis penyiangan yaitu:

1). Mengetahui pertimbangan-pertimbangan dalam menyiangi bahan pustaka

2). Mengetahui siapa saja yang terlibat dalam proses penyiangan

3). Mengetahui jangka waktu dilakukan penyiangan koleksi

f. Evaluasi

Evaluasi koleksi berarti menilai atau mengukur kualitas kegunaan atau manfaat koleksi perpustakaan terhadap pengguna. Dalam hal ini kegiatan yang dilakukan adalah mengidentifikasi metode evaluasi bahan pustaka

Di Perpustakaan Sekolah Tinggi Pembangunan Masyarakat Desa Yogyakarta dalam seleksi menggunakan pandangan ketiga yaitu mempertimbangkan kualitas dan popularitas. Karena koleksi yang berorientasi pada ilmu sosial sangat membutuhkan pemutakhiran. Sehingga untuk menjaga kerelevanan dengan kebutuhan pengguna maka digunakan padangan ketiga yaitu Pluralistik yang menyeimbangkan antara pandangan liberal dan tradisional. Penyeleksian koleksi pada perpustakaan Sekolah Tinggi Pembangunan Masyarakat Desa
Yogyakarta menggunakan alat bantu seleksi katalog penerbit.

Sebuah perpustakaan terbangun dari kumpulan berbagai elemen yang menopang sebuah perpustakaan. elemen tersebut terdiri dari gedung, koleksi, dana operasional dan sumber daya manusia. Salah satu elemen tersebut yaitu koleksi menjadi salah satu elemen penting yang menentukan eksistensi perpustakaan di tengah masyarakat. eksistensi sebuah perpustakaan dapat dilihat dari banyaknya pengguna yang mengakses perpustakaan. kemampuan yang dapat memotivasi masyarakat untuk mengakses perpustakaan adalah koleksi yang berkualitas, kerelevanan dengan kebutuhan pengguna serta jaminan kemudahan akses terhadap koleksi tersebut. Kualitas koleksi dipengaruhi dan disesuaikan dengan kebutuhan pengguna serta dipengaruhi oleh proses pengadaan koleksi. Sedangkan kemudahan mengakses koleksi perpustakaan sangat dipengaruhi oleh proses pengolahan serta pelayanan bahan pustaka. Untuk memenuhi kebutuhan pengguna dari sisi yang memiliki kuantitas dan kualitas tentu dibutuhkan konsep pengembangan koleksi.

\section{E. PENUTUP}

Kebijakan Pengembangan koleksi merupakan prosedur yang mengatur dalam mengalokasikan sumber daya informasi di perpustakaan, bertujuan untuk menentukan apa yang harus dikembangkan dan menentukan peningkatan layanan. Perpustakaan perlu melakukan komunikasi dengan civitas akademika sebagai pengguna potensi perpustakaan perguruan tinggi untuk melihat hal yang mesti diprioritaskan dalam menentukan pembuatan kebijakan pengembangan koleksi yang dilakukan secara berkelanjutan. Eksistensi perpustakaan sebagai garda ilmu pengetahuan tidak bisa mengembangan koleksi tanpa adanya kebijakan, prosedural dan manajemen sumber daya informasi yang baik. 
Perpustakaan harus memiliki kebijakan pengembangan koleksi sebagai peta arah kegiatan pengembangan koleksi di perpustakaan, untuk meningkatkan daya guna perpustakaan dan kerelevanan dengan kebutuhan masyarakat pengguna dimana perpustakaan tersebut berada. Namun pada kenyataannya masih banyak perpustakaan yang belum memiliki kebijakan pengembangan koleksi, sehingga koleksi yang ada kurang dimanfaatkan karena sering tidak relevan dengan kebutuhan yang ada. Selain itu, sulitnya menjalankan proses pengadaan yang terarah sesuai dengan visi dan misi perpustakaan dan lembaga induk.

Untuk setiap perpustakaan diharapkan dapat menyediakan kebijakan pengembangan koleksi dan Standar Operasional Perpustakaan sebagai petunjuk arah kegiatan yang ada di perpustakaan.

\section{DAFTAR PUSTAKA}

Adams, B., \& Noel, B. (2008). Circulation Statistics In The Evaluation Of Collection Development. Collection Building, 27(2).

Darmono. (2001). Manajemen Dan Tata Kerja Perpustakaan Sekolah. Jakarta: Grasindo.

Evan, G., \& Saponaro, M. Z. (2005). Developing And Information Center Collection. London: Libarries.

Greer, R., \& Hale, M. L. (1985). Models Related To Community Analysis. Offset.

Jhonson, P. (2009). Fundamentals Of Collection Depelopment And Management. Chicago: American Library Association.

Lexi, M. J. (2008). Metodelogi penelitian kuanlitatif. Bandung: Rosda.

Montviloff, V. (1990). National Information Policies: A handbook on the formulation, approval, implementation and operation of a national policy on information. Paris: UNESCO.

Qalyubi, S. (2007). Dasar-dasar Ilmu Perpustakaan dan Informasi. Yogyakarta: UIN Sunan Kalijaga.

Yulia, Y. (2009). Pengembangan Koleksi. Jakarta: Universitas Terbuka. 
